\title{
Family type and accidents in preschool children
}

\author{
JANE WADSWORTH, IOANNA BURNELL, BRENT TAYLOR, AND NEVILLE \\ BUTLER \\ From the Child Health and EUucation Study, Department of Child Health, University of Bristol, Bristol, UK
}

SUMMARY Children living in single-parent families or stepfamilies were found to be more likely to suffer accidental injuries in their first five years of life than children living with two natural parents. Frequent household moves, low maternal age, and perceived poor behaviour in the child were all more strongly associated with overall accident rates than family type, and these disadvantages were more common in atypical families. Family type appeared to be the most important influence on hospital admission after accidents. Overall, there was a close similarity in accident rates between children of single-parent families and stepfamilies, and both groups were more at risk than children living with both natural parents.

Accidents in childhood are an important cause of morbidity and admissions to hospital and in Jackson's view constitute an epidemic in the Western world. ${ }^{1}$ Fatal accidents account for almost one-third of all deaths to children between the ages of 1 and $14 .^{2}$ Most fatal accidents to preschool children happen at home, while over half the deaths from accidents in children between the ages of 1 and 14 years result from road traffic accidents. ${ }^{3}$ An understanding of the causes might be expected to reduce accident rates through intervention. From 1970 to 1975 (the years with which the present study is concerned) the number of accidental deaths among preschool children fell. ${ }^{4}$ The factors responsible for this encouraging trend are not clear. Although deaths from accidental injury contribute largely to childhood mortality, the overwhelming majority of children's accidents are not fatal, and they vary in severity from trivial to those resulting in severe handicap.

Many accident hazards surround young children, and part of growing-up must be learning to cope with such hazards. Children must not be needlessly exposed, however, and it is also important that safety standards in the home are continually reviewed and improved. The reduction after the introduction of childproof packaging cited by Craft and Sibert ${ }^{5}$ in the number of young children admitted to hospital having swallowed aspirin is a likely example of beneficial environmental manipulation in response to an identified problem.

It seems unlikely that hazardous environments alone can account for why some children have accidents more often than others, and many studies using various methods and hypotheses have investigated possible biological or social influences on the problem. Shelmerdine and Rigby ${ }^{6}$ thought that parental supervision was an important factor, while several other authors ${ }^{7-12}$ thought that familyo stress or marital disharmony was associated with childhood accidents; there may well be a relation ship between family stress and the vigilance of parental supervision. These studies, mainly on hospital patients, have examined aspects of families with children having accidents or have compared small numbers of accident cases with selected controls.

Atypical family situations, single-parent families or stepfamilies, may be a sign of, or result in family stress. In the present study based on a large national cohort, and therefore likely to be generally representative not only of children who have accidents but also of children who do not have accidents, we have examined the possible effect of family type on rates and types of accident in children during their first five years.

\section{Subjects and methods}

The Child Health and Educational Study (CHES) is a longitudinal follow-up of 17588 children born in Britain in one week in April 1970. ${ }^{12}$ Information on the health and social circumstances of the mother and child was obtained at the child's birth, and five years later in 1975 the children living in England, Wales, and Scotland were recontacted (12 743 children, $79.6 \%$ of eligible children from the birth survey). The children who were untraced in $1975(20.4 \%)$ were not a random sample of the population but were 
more likely to have been children of young or unmarried mothers or children of minority ethnic groups. At the five-year interview, information was obtained from the mother by the health visitor on a wide variety of medical, social, and developmental topics, including information on all accidents the child had sustained since birth, provided that the injury was sufficiently serious to require medical attention. This definition of injury relies on the mother's opinion and recall but is useful for including minor injuries, even though it may make it difficult to draw comparisons with other studies. ${ }^{13}$ The circumstances of the accident were recorded, including type of injury, place of accident, age, and treatment of the child. Details of the family structure at the child's fifth birthday were also gathered, including information about the parents, the number of siblings, and whether there had been any parental changes since the child's birth.

The analysis for this paper used data from singleton births for whom information was obtained both during the first week of life and when the children were 5 years old. Over $95 \%$ of these children had been born to married women. At age 5, 91\% of these children were living with both natural parents, $6 \%$ were living with one natural parent, and $3 \%$ were living with one natural and one new parent (stepfamilies). Over $70 \%$ of children living with one parent had been born to married women. The study population for this paper comprised all singleton children living in single-parent families or stepfamilies at 5 years of age and for control purposes a $20 \%$ random sample of children who had always lived with both natural parents. (A study of factors associated with accidents to children in the whole cohort is currently under way.) Children who were not living with either natural parent or whose mother's marital status at birth was not known were not included in the analysis. Comparisons have been drawn between children living with both natural parents (2482) and those who had experienced some kind of atypical family situation, whether in a single-parent family (719) or in a stepfamily (342).

Preliminary cross tabulations followed by stepwise logistic regression analysis were used to explore the nature of the association between type of family and childhood accidents. Other variables considered in the analyses were the child's sex, whether or not there were older or younger siblings in the household at five years, the number of times the family had moved house during the five years, the child's behaviour score ${ }^{14}$ and the social index. ${ }^{15}$ The child's behaviour score was obtained from the parent's response to 31 behavioural items as they applied to the child. Those children whose scores fell in the upper quartile of the distribution were considered to have poor behaviour scores. The social index is a composite assessment of the family socioeconomic status including parental education, domestic overcrowding, tenure of accommodation, type of neighbourhood, and paternal occupation. Where there were missing data for any of the factors assessed (never more than 5\% for any variable and usually less than $1 \%$ ) as complete a population as possible was used.

\section{Results}

Table 1 shows for the three family types the overall rates of any accident (at least one), repeated accidents (two or more), and rates of hospital admission for at least one night after accidents. It can be seen that there were differences in children's accident rates between the different family types. Children in stepfamilies were more likely to have had an accident reported by their mother during their first five years of life than children from two-parent families. Children in stepfamilies were also more likely to have repeated accidents (two or more). Children in single-parent families were slightly more likely to have accidents or repeated accidents than children in two-parent families, but the differences were less pronounced than for children in stepfamilies.

Table 1 Any accident, repeated accident, and hospital admission rates after accident during the first five years by family type

\begin{tabular}{|c|c|c|c|c|}
\hline \multirow[b]{2}{*}{ Family type } & \multirow[b]{2}{*}{ No } & \multicolumn{2}{|c|}{ Percentage of children with: } & \multirow{2}{*}{$\begin{array}{l}\text { Hospital } \\
\text { admission } \\
\text { after } \\
\text { accident }\end{array}$} \\
\hline & & $\geqslant 1$ accident & $\geqslant 2$ accidents & \\
\hline $\begin{array}{l}\text { Two parent } \\
\text { Stepfamily } \\
\text { One parent }\end{array}$ & $\begin{array}{r}2482 \\
342 \\
719\end{array}$ & $\begin{array}{l}42 \cdot 7 \\
52 \cdot 6 \\
47 \cdot 3\end{array}$ & $\begin{array}{l}11 \cdot 1 \\
17 \cdot 8 \\
13 \cdot 1\end{array}$ & $\begin{array}{r}5 \cdot 8 \\
10 \cdot 8 \\
10 \cdot 3\end{array}$ \\
\hline
\end{tabular}

Nearly twice the proportion of children in both stepfamilies and single-parent families were admitted to hospital after accidents compared with children living with two natural parents. Table 2 shows the types of injury resulting from accidents. The mothers' reports of the injuries did not allow any assessment of severity, but all three types of injury shown here have the potential for serious consequences. Head injuries and suspected poisonings were more often reported for children in stepfamilies, and burns and scalds in children of one-parent families.

Many factors are associated with accident rates, and table 3 illustrates rates of accident, repeated accident, and hospital admission after accident selected by social and biological factors. The most pronounced difference in rates was that between boys and girls. 
Table 2 Selected types of injury by family status (\%)

\begin{tabular}{|c|c|c|c|c|}
\hline & $\begin{array}{l}\text { Two-parent } \\
\text { family } \\
(n=2482)\end{array}$ & $\begin{array}{l}\text { Stepfamily } \\
(n=342)\end{array}$ & $\begin{array}{l}\text { One-parent } \\
\text { family } \\
(\mathrm{n}=719)\end{array}$ & $x$ \\
\hline No accidents & $\begin{array}{l}1423 \\
(57 \cdot 3)\end{array}$ & $\begin{array}{l}163 \\
(47 \cdot 4)\end{array}$ & $\begin{array}{l}379 \\
(52 \cdot 7)\end{array}$ & $\begin{array}{l}14.2 \\
p<0.001\end{array}$ \\
\hline Head injury & $\begin{array}{c}376 \\
(15 \cdot 1)\end{array}$ & $\begin{array}{l}75 \\
(21 \cdot 9)\end{array}$ & $\begin{array}{l}119 \\
(16 \cdot 5)\end{array}$ & $\begin{array}{l}10.4 \\
p<0.01\end{array}$ \\
\hline $\begin{array}{l}\text { Burns and } \\
\text { scalds }\end{array}$ & $\begin{array}{l}137 \\
(5 \cdot 5)\end{array}$ & $\begin{array}{c}24 \\
(7 \cdot 0)\end{array}$ & $\begin{array}{l}61 \\
(8 \cdot 5)\end{array}$ & $\begin{array}{l}10.0 \\
p<0.01\end{array}$ \\
\hline $\begin{array}{l}\text { Suspected } \\
\text { poisoning }\end{array}$ & $\begin{array}{l}131 \\
(5 \cdot 3)\end{array}$ & $\begin{array}{l}29 \\
(8 \cdot 5)\end{array}$ & $\begin{array}{l}51 \\
(7 \cdot 1)\end{array}$ & $\begin{array}{l}8.3 \\
p<0.03\end{array}$ \\
\hline
\end{tabular}

Note: Not all types of injury are listed, and some children sustained injuries of more than one type.

The mother's age was strongly associated with accidents as was family structure and stability in terms of household moves. The child's behaviour score was also related to accident rates, but it must be remembered that the assessment of behaviour was made by the mother after the accident(s) had occurred. The weakest association with accident rates was that of the social index, where only hospital admissions for accidents were significantly related. These biological and social associations of accident in children were also found to be associations of family type (table 4).

To investigate the relation between the associated factors and accident rates, stepwise logistic multiple regression was used. For the any accident rate and the repeated accident rate, family type was not significantly associated after adjustment for other factors. For hospital admissions after accidents, family type appeared as the most significant factor. Table 5 shows the factors used in the logistic regression analysis in order of significance. Overall accidents during the first five years were more likely in boys with poor behaviour scores at 5 years from families frequently moving house, and hospital admissions after accident were most likely in children living in single-parent families or stepfamilies with older siblings, young mothers, and poor behaviour scores. Table 6 shows the unadjusted hospital admission rates for accidents by each family type and the persisting highly significant rates even after adjustment for the child's behaviour score, the presence or absence of older siblings, and the mother's age at the child's birth.

\section{Discussion}

Family type at five years has been shown to be associated with likelihood of accident during the first five years. The differential accident rates, be they reported accidents or hospital admissions after accidents, among children from different types of $\varnothing$ family are striking. The fact that children of young oro unmarried mothers are underrepresented in this study due to difficulties in tracing means that our

Table 3 Any accident, repeated accident, and hospital admission rates after accident by selected biological and social factors

\begin{tabular}{|c|c|c|c|}
\hline & \multicolumn{3}{|c|}{ Percentage of study children with } \\
\hline & $\geqslant 1$ accident & $\geqslant 2$ accidents & $\begin{array}{l}\text { Hospital admission } \\
\text { after accident }\end{array}$ \\
\hline \multicolumn{4}{|c|}{ Household siblings at 5 years: } \\
\hline $\begin{array}{l}\text { No older } \\
\text { One older }\end{array}$ & $45 \cdot 7$ & $11 \cdot 6$ & $6 \cdot 5$ \\
\hline $\begin{array}{l}\text { One older } \\
\text { Two or more older }\end{array}$ & 43.0 & $13 \cdot 3$ & 6.5 \\
\hline $\begin{array}{l}\text { Two or more older } \\
\text { No younger }\end{array}$ & 44.8 & 11.5 & $9 \cdot 1$ \\
\hline $\begin{array}{l}\text { No younger } \\
\text { One younger }\end{array}$ & 44.0 & 11.9 & 6.9 \\
\hline $\begin{array}{l}\text { One younger } \\
\text { Two or more younger }\end{array}$ & $45 \cdot 1$ & $12 \cdot 4$ & $7 \cdot 4$ \\
\hline $\begin{array}{l}\text { Two or more younger } \\
\text { Household moves 0-5 y }\end{array}$ & $45 \cdot 9$ & 12.9 & $8 \cdot 2$ \\
\hline \multicolumn{4}{|c|}{$\begin{array}{l}\text { 1wo or more younger } \\
\text { Household moves } 0-5 \text { years: }\end{array}$} \\
\hline $\begin{array}{l}\text { None } \\
\text { One }\end{array}$ & $38 \cdot 8$ & $9 \cdot 5$ & 5.4 \\
\hline $\begin{array}{l}\text { One } \\
\text { Two }\end{array}$ & $46 \cdot 7$ & $12 \cdot 3$ & $7 \cdot 3$ \\
\hline $\begin{array}{l}\text { Two } \\
\text { Three or more }\end{array}$ & $47 \cdot 5$ & $12 \cdot 4$ & $8 \cdot 8$ \\
\hline $\begin{array}{l}\text { Three or more } \\
\text { Sex: }\end{array}$ & $50 \cdot 9$ & $17 \cdot 9$ & $9 \cdot 3$ \\
\hline \multicolumn{4}{|l|}{$\begin{array}{l}\text { Three or more } \\
\text { Sex: }\end{array}$} \\
\hline $\begin{array}{l}\text { Boys } \\
\text { Girls }\end{array}$ & $\begin{array}{l}50 \cdot 6 \\
39 \cdot 3\end{array}$ & $\begin{array}{r}15 \cdot 5 \\
8.7\end{array}$ & $\begin{array}{l}7.5 \\
6.8\end{array}$ \\
\hline \multicolumn{4}{|c|}{$\begin{array}{l}\text { Girls } \\
\text { Rutter behaviour score at } 5 \text { years: }\end{array}$} \\
\hline 1st quartile (good) & $39 \cdot 0$ & $9 \cdot 1$ & $4 \cdot 4$ \\
\hline 2nd quartile & $42 \cdot 4$ & 8.8 & 6.4 \\
\hline 3rd quartile & $47 \cdot 7$ & $14 \cdot 4$ & $7 \cdot 3$ \\
\hline 4th quartile (bad) & $48 \cdot 3$ & $15 \cdot 6$ & 9.9 \\
\hline \multicolumn{4}{|c|}{$\begin{array}{l}\text { 4th quartile (bad) } \\
\text { Maternal age at child's birth: }\end{array}$} \\
\hline$<20$ & $51 \cdot 6$ & $16 \cdot 0$ & $9 \cdot 6$ \\
\hline $20-29$ & 45.0 & $12 \cdot 1$ & $7 \cdot 4$ \\
\hline$\geqslant 30$ & 39.9 & $10 \cdot 1$ & 4.9 \\
\hline \multicolumn{4}{|l|}{$\begin{array}{l}\geq 30 \\
\text { Social index: }\end{array}$} \\
\hline Advantaged & $41 \cdot 7$ & $11 \cdot 3$ & $5 \cdot 6$ \\
\hline Average & $45 \cdot 0$ & 11.4 & $7 \cdot 0$ \\
\hline Disadvantaged & $46 \cdot 5$ & $13 \cdot 6$ & $8 \cdot 7$ \\
\hline
\end{tabular}


Table 4 Family type by biological and social variables

\begin{tabular}{|c|c|c|c|}
\hline & \multicolumn{3}{|c|}{ Percentage of study children with } \\
\hline & Two-parent family & Stepfamily & One-parent family \\
\hline \multicolumn{4}{|c|}{ Household siblings at 5 years: } \\
\hline No older & $40 \cdot 2$ & $47 \cdot 1$ & $39 \cdot 1$ \\
\hline One older & $34 \cdot 3$ & $31 \cdot 6$ & 30.7 \\
\hline Two or more older & $25 \cdot 5$ & $21 \cdot 3$ & $30 \cdot 2$ \\
\hline No younger & $52 \cdot 8$ & $40 \cdot 9$ & $69 \cdot 1$ \\
\hline One younger & $39 \cdot 4$ & $46 \cdot 2$ & $25 \cdot 2$ \\
\hline Two or more younger & 7.8 & $12 \cdot 9$ & $5 \cdot 7$ \\
\hline \multicolumn{4}{|c|}{ Household moves $0-5$ years: } \\
\hline None & $42 \cdot 7$ & $8 \cdot 8$ & $28 \cdot 1$ \\
\hline One & $37 \cdot 2$ & 27.9 & $32 \cdot 7$ \\
\hline Two & $10 \cdot 8$ & 19.7 & $15 \cdot 8$ \\
\hline Three or more & $9 \cdot 2$ & 43.6 & $23 \cdot 3$ \\
\hline \multicolumn{4}{|l|}{ Sex } \\
\hline Boys & $51 \cdot 5$ & $50 \cdot 0$ & $50 \cdot 5$ \\
\hline Girls & $48 \cdot 5$ & $50 \cdot 0$ & $49 \cdot 5$ \\
\hline \multicolumn{4}{|c|}{ Rutter behaviour score at 5 years } \\
\hline 2nd quartile & $25 \cdot 1$ & $20 \cdot 4$ & $18 \cdot 4$ \\
\hline 3rd quartile & $26 \cdot 5$ & $22 \cdot 7$ & $26 \cdot 4$ \\
\hline 4th quartile (bad) & $25 \cdot 4$ & 36.9 & $35 \cdot 5$ \\
\hline \multicolumn{4}{|c|}{ Maternal age at child's birth: } \\
\hline$<20$ & 9.6 & $27 \cdot 4$ & $18 \cdot 5$ \\
\hline $20-29$ & $66 \cdot 7$ & $67 \cdot 0$ & $62 \cdot 3$ \\
\hline$\geqslant 30$ & $23 \cdot 7$ & $5 \cdot 7$ & $19 \cdot 2$ \\
\hline \multicolumn{4}{|l|}{ Social index: } \\
\hline Advantaged & $36 \cdot 7$ & $16 \cdot 1$ & $11 \cdot 4$ \\
\hline Average & $37 \cdot 3$ & $41 \cdot 5$ & $29 \cdot 1$ \\
\hline Disadvantaged & $26 \cdot 0$ & $42 \cdot 4$ & $59 \cdot 5$ \\
\hline
\end{tabular}

Table 5 Factors influencing accidents in order of significance in logistic regression analyses

\begin{tabular}{|c|c|c|c|c|c|c|}
\hline & $\geqslant 1$ accident & & $\geqslant 2$ accidents & & $\begin{array}{l}\text { Hospital admission } \\
\text { after accident }\end{array}$ & \\
\hline Significant factors & $\begin{array}{l}\text { Child's sex } \\
\text { Household moves } \\
\text { Child's behaviour }\end{array}$ & $* * * *$ & $\begin{array}{l}\text { Child's sex } \\
\text { Household moves } \\
\text { Child's behaviour }\end{array}$ & $* * * *$ & $\begin{array}{l}\text { Family type } \\
\text { Mother's age } \\
\text { Child's behaviour } \\
\text { Older siblings }\end{array}$ & $* * *$ \\
\hline Non-significant factors & $\begin{array}{l}\text { Mother's age } \\
\text { Older sibling } \\
\text { Family type } \\
\text { Younger siblings }\end{array}$ & & $\begin{array}{l}\text { Older siblings } \\
\text { Mother's age } \\
\text { Family type } \\
\text { Younger siblings }\end{array}$ & & $\begin{array}{l}\text { Household moves } \\
\text { Child's sex }\end{array}$ & \\
\hline
\end{tabular}

Table 6 Hospital admission after accident by family status adjusted for intervening variables

\begin{tabular}{lrcr}
\hline & No & $\begin{array}{l}\text { Unadjusted rates } \\
(\%)\end{array}$ & $\begin{array}{l}\text { Adjusted rate } \\
(\%)\end{array}$ \\
\hline Two-parent family & 2405 & 5.8 & 6.1 \\
Stepfamily & 318 & 10.1 & $9 \cdot 2$ \\
One-parent family & 646 & 10.6 & 10.0 \\
\hline
\end{tabular}

conclusions are based on a minimal estimate of accidents among these children. Among the possible reasons for the increased accident rate associated with atypical (single or step) families is the greater likelihood that parents in such families may be preoccupied or unaware of potential dangers. The families may be more likely to be living in potentially dangerous environments, or the children themselves may be upset by the arrival or loss of either a father or mother. The limitations of retrospective epidemiological studies such as the present one preclude detailed assessment of any of these possibilities. Nevertheless, careful scrutiny of our results provides insights into some of the factors associated with accident rates. For instance, children in one-parent families were the most likely to be burnt or scalded, and these types of accidents are more likely to happen if either the child is not well supervised or the household equipment is of poor standard-reflections of some personal and financial difficulties facing lone parents with sole responsibility for their children. The overall higher accident rates among children in stepfamilies suggest 
that, on the one hand, some children may have difficulty in adjusting to the loss of one parent and the substitution of another or, on the other hand, that the parent's changes in family structure and responsibilities results in less vigilant supervision.

Interpretation of the multivariate analyses of the accident rates (both any accident and repeated accidents) shows that family type, per se, is of less importance than other factors. As shown in table 4, however, both stepfamilies and single-parent families tend to have young mothers, frequent household moves, and children whose mothers more often perceive behaviour problems; these are all factors associated with increased accident rates.

The different associations of "any" accident compared with those of hospital admission after accident raise the possibility that there may be (at least) two forms of accident. ${ }^{18}$ Hospital admission after accidents was strongly associated with family type, suggesting either that children from stepfamilies or single-parent families are more likely than other children to injure themselves seriously, or that hospital casualty officers pursue a more cautious admission policy for children living in atypical families. There seems little doubt, however, from the results of this study that an atypical family situation is an important associated influence on accident rates in early childhood.

This paper is developed from a study of one-parent families supported by the Department of Health and Social Security. The Child Health and Educational Study (CHES) five-year follow-up was funded from a project grant from the Medical Research Council to the department of child health in the University of Bristol. Additional financial support was received from Action Research for the Crippled Child and from the National Birthday Trust Fund. We gratefully acknowledge the co-operation of area health authorities, health boards, and health visitors throughout England, Scotland, and Wales and the contributions of previous CHES survey workers to the research.
JW (in part) and BT are supported by the Riyadh Al Kharj Hospital Programme.

Correspondence to: Mrs Jane Wadsworth, Department of Child Health, Royal Hospital for Sick Children, St Michaels Hill, Bristol BS2 8BJ.

\section{References}

1 Jackson RH. Hazards to children in traffic. Arch Dis Child 1978; 53: 807-13.

${ }^{2}$ MacFarlane A. Child deaths from accident: place of accident. Population Trends 1979; 15: 10-5.

${ }^{3}$ MacFarlane A, Fox J. Child deaths from accidents and violence. Population Trends 1978; 12: 22-7.

${ }^{4}$ Wells N. Accidents in childhood. Office of Health Economics Briefing 1981; 17: 1-8.

${ }^{5} \mathrm{Craft} \mathrm{AW}$, Sibert JR. Accidental poisoning in children. $\mathrm{Br}$ J Hosp Med 1977; 18: 469-78.

${ }^{6}$ Shelmerdine HR, Rigby MJ. Home accident survey. Health and Social Services 1974; 74: 542-3.

${ }^{7}$ Backett EM, Johnston AM. Social patterns of road accidents to children. $\mathrm{Br}$ Med J 1959; i: 409-13.

${ }^{8}$ Sobel R. The psychiatric implications of accidental poisoning in childhood. Pediatr Clin N Am 1970; 17: 653-95.

${ }^{9}$ Husband P, Hinton P. Families of children with repeated accidents. Arch Dis Child 1972; 47: 396-400.

${ }^{10}$ Plionis E. Family functioning and childhood accident occurrence. Am J Orthopsychiatry 1977; 47: 250-63.

${ }^{11}$ Brown GW, Davidson S. Social class, psychiatric disorderō $\vec{\varphi}$ of mother and accidents to children. Lancet 1978; i: 378-80.

${ }^{12}$ Taylor B, Wadsworth J, Golding J, Butler N. Breast feeding, bronchitis and admissions for lower respiratory illness and gastroenteritis during the first five years. Lancet 1982; i: 1227-9.

${ }^{13}$ Calnan M, Wadsworth M. Accounting for accidental injury in childhood. In: Burman SB, Genn HG, eds. Accidents in the home. London: Croom Helm, 1977.

${ }^{14}$ Rutter M, Tizard J, Yule W, Graham P, Whitmore K. Isle of Wight 1964-74. Psychol Med 1976; 6: 313-32.

${ }^{15}$ Osborn AF, Morris AC. The rationale for composite index of social class and its evaluation. Br J Sociol 1978; 30: $39-60$.

${ }^{16}$ Taylor B, Wadsworth J, Butler NR. Teenage mothering: hospitalisation and accidents during the first five years. Arch Dis Child (in press). 